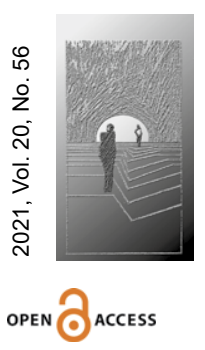

\title{
Godność dziecka w jezuickiej myśli pedeutologicznej okresu staropolskiego
}

\section{STRESZCZENIE}

CEL NAUKOWY: Celem artykułu jest ukazanie, jaką wizję, koncepcję dziecka, jego godności propagowano w jezuickiej myśli pedeutologicznej.

PROBLEM I METODY BADAWCZE: Aby odpowiedzieć na to pytanie, poddano analizie dzieła czołowych pedagogów jezuickich, które były używane w procesie przygotowania zawodowego nauczycieli w seminariach nauczycielskich.

PROCES WYWODU: Jezuicki system szkolnictwa zorganizowany został na podstawie zasad zapisanych w Ratio studiorum - ustawie tworzonej i udoskonalanej przez kilka dziesięcioleci. Regulowała ona prawa i obowiązki wszystkich podmiotów procesu kształcenia i wychowania. Aby zrealizować założenia i cele jezuickiej edukacji, potrzebni byli dobrze przygotowani nauczyciele. Zakon, wychodząc naprzeciw tym potrzebom, podczas II Kongregacji Generalnej w 1565 roku powołał do życia instytucję służącą kształceniu nauczycieli - rodzaj seminarium nauczycielskiego - pod nazwą „Seminarium nostrorum”. W seminariach pracowali wybitni pedagodzy jezuiccy - autorzy podręczników, które były przedmiotem analizy pod kątem propagowanej w nich wizji dziecka, jego godności i miejsca w procesie edukacyjnym.

WYNIKI ANALIZY NAUKOWEJ: Analiza treści zawartych w dziełach pedagogicznych używanych w procesie przygotowania zawodowego nauczycieli pozwala na odczytanie pozycji dziecka w procesie kształcenia i wychowania w sposób bezpośredni poprzez uznanie jego królewskiej godności wyrażonej w szacunku do dzieciństwa, jego praw, trosk, możliwości rozwojowych, a także w sposób pośredni - wyrażony w opisie roli zawodowej nauczyciela, jego misji wobec najmłodszych uczniów, w konkretnych wskazaniach metodycznych dla przyszłych nauczycieli.

WNIOSKI, INNOWACJE, REKOMENDACJE: Myśl pedeutologiczna zrekonstruowana na podstawie lektury najważniejszych dzieł staropolskich jezuickich pedagogów kształcących nauczycieli dla szkół jezuickich odzwierciedla ówczesne myślenie o głównych aktorach procesu edukacyjnego: uczniach i nauczycielach. Pozwala na odczytanie roli każdego z nich, a także ich wzajemnej relacji w procesie kształcenia i wychowania. Centralną pozycję zajmuje w nim uczeń, posiada on „królewską godność", nauczyciel zaś pełni funkcję służebną, wymagającą z jednej strony pokory (zasada dostosowania, indywidualizacji), a z drugiej - wszechstronnego i gruntownego przygotowania 


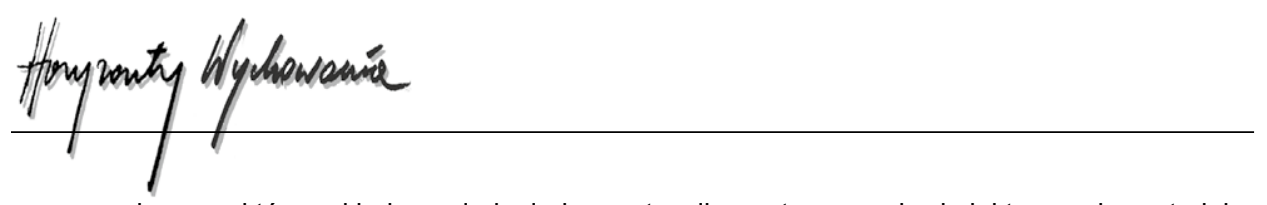
zawodowego, które zakłada posiadanie kompetencji merytorycznych, dydaktycznych, metodologicznych i osobowościowych.

$\rightarrow$ SŁOWA KLUCZOWE: DZIECKO, GODNOŚĆ, NAUCZYCIEL, PEDEUTOLOGIA, JEZUICI,

\begin{abstract}
Child's Dignity in the Jesuit Pedeutological Thought of the Old Polish Period

RESEARCH OBJECTIVE: The objective of this article is to show the vision of a child and his/her dignity promoted in the Jesuit pedeutological thought.
\end{abstract}

THE RESEARCH PROBLEM AND METHODS: In order to answer this question, works of the greatest Jesuit pedagogues were analysed, as those works were used in the process of educating teachers in teacher seminaries.

THE PROCESS OF ARGUMENTATION: The Jesuit system of education was organised according to the principles included in Ratio Studiorum, an act that has been created and improved for several centuries. The act regulated the rights and obligations of all the subjects taking part in the process of teaching and upbringing. In order to fulfil the objectives and assumptions of Jesuit education, well-prepared teachers were needed. To meet those needs, during the Second General Congregation of 1565 the Order established an institution for educating teachers. It was a kind of a teacher seminary called "Seminarium Nostrorum." Outstanding Jesuit pedagogues worked in those seminaries - authors of the textbooks that were analyzed in terms of their vision of the children, his/her dignity and place in the educational process.

RESEARCH RESULTS: The analysis of the content of the pedagogical works used in the process of professional training of teachers allows uncovering the child's position in the process of education and upbringing in a direct way by recognizing his/her royal dignity, expressed in respect for childhood, his/her rights, concerns, developmental opportunities, and indirectly - expressed in the description of the teacher's professional role, his mission towards the youngest students, in specific methodological guidelines for future teachers.

CONCLUSIONS, INNOVATIONS AND RECOMMENDATIONS: The pedeutological thought reconstructed on the basis of reading the most important works of Old Polish Jesuit educators training teachers for Jesuit schools reflects of that time thinking about the main actors of the educational process: students and teachers. It allows reading the role of each of them, as well as their mutual relationship in the process of education and upbringing. The student has a central position in it, has "royal dignity," while the teacher plays a servitude role, which requires from him humility on the one hand (the principle of adaptation, individualization), and on the other - comprehensive and thorough professional preparation, which assumes possessing substantive, didactic, methodological and personal competences.

\title{
$\rightarrow$ KEYWORDS: CHILD, DIGNITY, TEACHER, PEDEUTOLOGY, JESUITS
}




\section{Pojęcie godności}

Termin „godność” używany jest w dwóch zasadniczo różnych znaczeniach: jako cecha wrodzona (ontyczna) i nabyta (kulturowa), na oznaczenie dwóch typów godności, tradycyjnie nazywanych osobową (bo przynależną człowiekowi jako osobie) i osobowościową. Pierwsza przysługuje człowiekowi wewnętrznie, druga - zewnętrznie. Kiedy filozofowie (antropolodzy filozoficzni, etycy) mówią o posiadaniu godności przez człowieka, mają zwykle na myśli jego bytowo (istotowo) wyróżnioną pozycję w świecie, którą zawdzięcza swej przynależności do (filozoficznie rozumianego) gatunku ludzkiego, czyli dzięki swej ludzkiej naturze. Godność osobowa przysługuje więc każdemu człowiekowi i jest wartością bezwzględną, przyrodzoną, uniwersalną, niestopniowalną, niezbywalną, nienaruszalną i absolutną. Zmienia się jedynie nasza świadomość istnienia tej godności oraz konkretne wyrazy jej respektowania (Mariański, 2019, s. 5). Ma swoją podstawę w ontycznej strukturze człowieka, dlatego jest niezależna od kontekstu historycznego i społecznego. Posiada ją zatem każdy człowiek, niezależnie od przynależności do danego narodu, klasy, rasy, religii, wykształcenia i zawodu. Mówiąc o ontycznym wymiarze bycia człowiekiem, wskazuje się, że zakresowo posiadanie godności sprowadza się do faktu bycia człowiekiem, a być człowiekiem, to być osobą, to mieć godność i odznaczać się godnością (Bronk, 2010, s. 85; Anzenbacher, 2006, s. 55).

To teoretyczne ujęcie pojęcia godności osobowej ma swoje implikacje praktyczne, na co wskazuje Katarzyna Stępień, kiedy pisze, że godność osobowa to

(...) właściwość człowieka wypływająca z jego specyficznej struktury bytowej, ujawniająca się w aktach rozumnego i wolnego działania; bytu osobowego, wskazująca na jego szczególną wartość ontyczną i związaną z tym nieredukowalność do roli środka (Stępień, 2016, s. 376).

Do tych dwóch aspektów godności, a więc godności osobowej, czyli niezniszczalnej, immanentnej właściwości wrodzonej, oraz godności osobowościowej, czyli nabytych przez człowieka cech i cnót, które świadczą o jego prawości, należy dodać trzeci aspekt, mianowicie godność os obistą, czyli indywidualne poczucie człowieka o byciu kimś, kto zajmuje ważną pozycję w społeczeństwie (de Tchorzewski, 2020, s. 165).

Godność człowieka wymaga, aby działał on w sposób świadomy i wolny. O ile godność osobowa jest wartością wynikającą z racji bycia osobą, to godność osobista (własna) jest właściwością indywidualną i specyficzną, właściwą każdej jednostce, nadbudowuje się ona poniekąd na godności osobowej. W przeciwieństwie do godności osobowej ta godność podlega zmienności historycznej i społecznej. Jej rozwój zależy od aspiracji jednostki i jej wrażliwości na wartości. Czynnikiem wzmacniającym własne poczucie godności jest skala wyznawanych wartości oraz stopień ich akceptacji nie tylko przez siebie, ale i przez innych. W ujęciu Janusza Mariańskiego godność osobista jest pewnym doświadczeniem wewnętrznym, które można by określić jako swoisty element samowiedzy. Takie poczucie godności kształtuje się i ujawnia w relacjach międzyludzkich i wiąże 


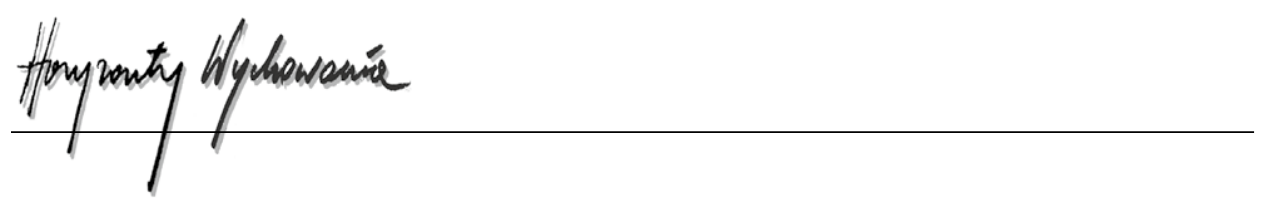

się z odczuciem granic, jakie człowiek wyznacza sam sobie w interakcji i jakie wyznacza partnerowi interakcji (Mariański, 2020, s. 28). Na ten interpersonalny charakter godności wskazują również Zdzisław Chlewiński i Zbigniew Zaleski. Według tych badaczy

(...) godność (z łac. dignitas), szczególna wartość człowieka jako osoby pozostającej w relacjach interpersonalnych (ostatecznie do osoby Boga), uzasadniających i usensowniających życie osobowe, a także pozytywnie wartościująca relacje do własnej osoby i grupy (np. zawodowej, klasowej, narodowej), z którymi się jednostka identyfikuje. Konstytuującym komponentem ustosunkowania się jest samoocena polegająca na przeżywaniu swojej wartości i pozytywnego obrazu, która motywuje do moralnie wartościowych zachowań, uodparniania się na wszelakie formy manipulacji i zniewalania oraz wpływa na radzenie sobie w sytuacjach trudnych. Godność zakłada poczucie wewnętrznej wolności, autodeterminacji (podmiotowości) i odpowiedzialności (Chlewiński i Zaleski, 1989, kol. 1231-1232).

W kontekście procesów edukacyjnych istotne jest rozpatrywanie godności ze względu na jej funkcję integrującą przymioty osoby, takie jak: rozumność - mądrość, wolność, odpowiedzialność, twórczość (por. Chałas, 2021, s. 36). W związku z tym w centrum refleksji pedagogicznej jest godność osobowa, osobowościowa i osobista. Jej rozumienie w tych wszystkich zakresach znaczeniowych implikuje cele i zadania, a także metody stosowane w praktyce kształcenia i wychowania dziecka.

\section{Godność dziecka w pedagogice ignacjańskiej}

Szkoła jako instytucja edukacyjna jest zobowiązana do tego, aby dzieciom i młodzieży stworzyć warunki do rozwijania ich indywidualności, do promowania własnego sposobu myślenia i wartościowania, do dojrzałego korzystania z wolności. Jezuicka szkoła okresu staropolskiego, ufundowana na założeniach pedagogiki ignacjańskiej, z racji swego zakorzenienia w chrześcijańskim systemie wychowania daje wyraz poszanowania godności we wszystkich jej wymiarach. Zaangażowanie jezuitów w rozwój powierzonych im chłopców zaowocowało stworzeniem sieci seminariów nauczycielskich, w których przygotowywano przyszłych nauczycieli do ich pracy dydaktyczno-wychowawczej. O tym, jak dużą wagę przykładano do kształcenia nauczycieli (bo przecież od jakości ich pracy zależały postępy uczniów), świadczą prace wybitnych pedagogów Towarzystwa Jezusowego (Królikowska, 2019).

Analiza treści zawartych w dziełach pedagogicznych używanych w procesie przygotowania zawodowego nauczycieli pozwala na odczytanie pozycji dziecka w procesie kształcenia i wychowania w sposób bezpośredni poprzez uznanie jego królewskiej godności wyrażonej w szacunku do dzieciństwa, jego praw, trosk, możliwości rozwojowych, a także w sposób pośredni, wyrażony w opisie roli zawodowej nauczyciela, jego misji wobec najmłodszych uczniów, w konkretnych wskazaniach metodycznych dla przyszłych nauczycieli.

Przejawem poszanowania godności dziecka w różnych jej wymiarach w jezuickich szkołach była zasada dostosowania czy adaptacji. Została ona przejęta z Ćwiczeń 
duchowych założyciela zakonu Ignacego z Loyoli. Proces dostosowania ćwiczeń duchowych do rekolektanta zazwyczaj dotyczy trzech poziomów: dostosowania do osób, dostosowania do warunków zewnętrznych i dostosowania do treści ćwiczeń (Królikowski, 2015b). Ta zasada znalazła swoje zastosowanie praktyczne w działalności edukacyjnej zakonu.

Metoda nauczania przyjęta przez Towarzystwo opiera się głównie na rozpoznaniu możliwości, potencjału każdego ucznia, a także wszelkich wpływów, jakim on podlega w trakcie swojego rozwoju. Zatem punktem wyjścia w procesie kształcenia jest diagnoza, która jednocześnie stanowi podstawę adaptacji metod nauczania. Nauczyciel musi przede wszystkim uwzględnić cały zespół czynników psychologicznych osoby, którą ma kształcić.

Antonio Possevino, autor słynnego dzieła Biblioteca selecta, które zawiera bardzo ważny rozdział De cultura ingeniorum, twierdził, że jedną z rzeczy, które są przyczyną błędów w procesie kształcenia intelektualnego, jest nieznajomość tego, co każdy uczeń może wnieść do procesu uczenia się, czyli nieznajomość jego potencjału. Dlatego Possevino mówi o różnych talentach (de varietate ingeniorum), następnie o konieczności i sposobie poznania każdego z uczniów (de necessitate ac ratione singula pernoscendi agemus), wreszcie o sposobie wyodrębnienia rodzaju kultury, który odpowiada każdemu (ud deinceps quae cuique cultio ad hibenda sit ordine dicatur) (Charmot, 1951, s. 182) ${ }^{1}$. Te twierdzenia Possevina nie są odosobnione. Można je znaleźć u wszystkich pedagogów Towarzystwa ${ }^{2}$, a także w ważniejszych dokumentach zakonnych, takich jak Konstytucje czy Ratio studiorum.

Jezuici już w XVI wieku mieli świadomość tego, co we współczesnej pedagogice jest oczywistością: dzieci są różne, konieczne jest ich poznanie, aby dostosować oddziaływania edukacyjne do ich potrzeb i możliwości. Jezuici stosowali zawsze tę zasadę adaptacji w kształceniu i wychowaniu, uznając ją za istotną. Uważali, że największym błędem w pracy edukacyjnej jest poszukiwanie własnej chwały nauczyciela. Wierzyli bowiem, że nauczanie jest służbą. Przynosi dobre efekty tylko wtedy, gdy jest nieustannie dostosowywane do możliwości asymilacji, jakie posiada uczeń. Niestrawna wiedza czyni więcej szkody niż inteligentne lenistwo (Charmot, 1951, s. 190).

Ignacy Loyola odwraca role w procesie nauczania: zasadnicza rola przypada uczniowi, natomiast nauczyciel działa jako osoba z „drugiego rzędu”, siedząca za uczniem, aby

\footnotetext{
${ }^{1}$ Possevino może być śmiało uznany za prekursora nowożytnej pedagogiki, zalecającego metodyczne badania charakterów indywidualnych, które pozwolą na ukierunkowanie dziecka w jego indywidualnym rozwoju.

${ }^{2}$ Na przykład Franciszek Sacchini używa analogii do orkiestry: trzeba kierować każdym uczniem tak jak każdym instrumentem w orkiestrze, bo każdy ma swoją partię, swoją melodię, swoje brzmienie. Nie mogą więc wszystkie dzieci być kształcone w jeden sposób. Nauczyciel powinien się zatroszczyć o wszystkich i dostosować odpowiednio do każdego (Sacchini, 1625, rozdz. 5, s. 37). Podobnie Józef de Jouvancy pisze, że nauczyciel będzie się starał poznać naturę każdego ucznia, aby móc go traktować zgodnie z jego zaletami i wadami oraz prowadzić go według jego upodobań. Kiedy z nim rozmawia, niech stara się poznać jego charakter, aby dostosować do niego to, co ma powiedzieć (Jouvancy, 1703, s. 83).
} 


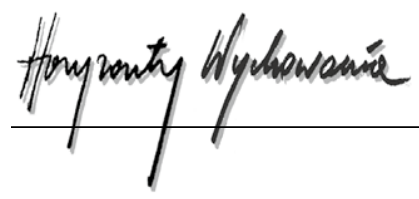

pomóc uczniowi - aktorowi pierwszego planu - dokonywać postępów w jego osobistym rozwoju. Nauczyciel powinien zatem pozostawać w całkowitej służbie ucznia ${ }^{3}$. W seminariach nauczycielskich prowadzonych przez zakon przekonywano przygotowujących się do tej roli jezuitów, że „edukacja dzieci jest rzeczą tyleż pożyteczną, co wielką. Bo faktycznie, czy istnieje dobro bardziej potrzebne, które miałoby większe znaczenie, które trwałoby dłużej i które rodziłoby mniej kłopotów i mniej niebezpieczeństw?" (Jouvancy, 1703, s. 132).

Pierwsze pedagogiczne dzieło wydane przez zakon jezuitów pt. Christiani pueri institutio ${ }^{4}$ autorstwa Juana Bonifacio pozwala uchwycić pozycję dziecka w procesie kształcenia i wychowania w kontekście roli zawodowej nauczyciela jezuickiej szkoły. W jednym z jego rozdziałów, De praeclara pueritia, novaeque aetatis defensione, autor wygłasza pochwałę młodości i jej pięknych przywilejów. Bonifacio przekonuje, że jezuita jest ojcem i zawsze pozostaje młody duchem i sercem. Zapomina o swoim dobru. Jest to podstawowy warunek, aby móc zrozumieć dzieci. Zrozumienie dzieci jest z kolei warunkiem dobrego kształcenia. Poznanie i zrozumienie dziecka wiążą się z koniecznością posiadania jednego z najbardziej niezbędnych talentów, znaku rozpoznawczego powołania nauczyciela i gwaranta jego sukcesu - talentu psychologicznego. Jego przejawem jest takt, roztropność, łagodność - cechy, które gwarantują poszanowanie godności młodego ucznia. Dzieło Juana Bonifacio jest przykładem dowartościowania i szacunku dla dzieciństwa. Jeśli dziś mówimy, że aż do XX wieku w procesie nauczania i wychowania ignorowano dziecko i dzieciństwo, to Bonifacio i jego dzieło są tego zaprzeczeniem. Dobra edukacja, w przekonaniu Juana Bonifacio, wymaga spełnienia podstawowego warunku, jakim jest dobór dobrych i wykształconych nauczycieli. Dobry nauczyciel to taki, który spełnia trzy kryteria: jest łagodny wobec ucznia, uczciwy i cechuje się erudycją. Ten, kto naprawdę chce być uznanym nauczycielem, powinien nauczać młodego człowieka nauk humanistycznych i cnotliwego życia. Dlatego nauczyciele sami powinni być uczciwi i uczeni. To są podstawy, na których opiera się chrześcijańska edukacja (Vergara Ciordia, 2012, s. 88).

Ta dialektyka kształcenia humanistycznego i wychowania moralnego była charakterystyczna dla myśli pedagogicznej okresu staropolskiego (Żołądź-Strzelczyk, 2002, s. 98). Do artes ad humanitatem et virtutem Erazma z Rotterdamu odwoływali się z głębokim przekonaniem wszyscy myśliciele i pisarze tej epoki, co oznacza, że humanizm Renesansu chciał wywrzeć swe piętno na edukacji (Delgado, 2002, s. 68-69). Do tego modelu edukacji odwołało się również szkolnictwo jezuickie. Jezuici próbowali wywierać wpływ na swoich uczniów bardziej własnym przykładem niż przekazywanym słowem.

${ }^{3}$ O tym służebnym wymiarze pracy nauczycieli mówi reguła 50 (Reguły wspólne dla nauczycieli klas niższych): „Niech [...] będzie nauczyciel we wszystkim, dzięki łasce Bożej, uważny i staranny, przydatny studentom tak w wykładach, jak gorliwy we wszystkich innych ćwiczeniach językowych. Nikogo niech nie lekceważy, niech ma na względzie zarówno ubogich, jak i bogatych, niech dba o postępy każdego ze swych podopiecznych" (Ratio studiorum, 2000, s. 90).

${ }^{4}$ Pierwsze wydanie: Christiani pueri institutio, adolescentiaeque perfugium: ad gymnasia eiusdem Societatis, Matias Gast, Salamanca 1575. Była to pierwsza europejska książka wydana w Chinach (por. Vergara Ciordia, 2012, s. 83; Alves Dias, 2014, s. 84-88). 
Nauczyciele jezuiccy przypominali sobie nawzajem, jak ważne jest pokochanie uczniów i jak najlepsze ich poznanie. Za każdym razem, kiedy udawało się zbliżyć do tego ideału, szkoła osiągała sukces.

Idee Jana Bonifacio podjęli i propagowali inni pedagodzy Towarzystwa: Franciszek Sacchini, Józef de Jouvancy czy polski jezuita Stefan Sczaniecki. Franciszek Sacchini, znając rzeczywistość szkolną i problemy nauczycieli, zredagował dwie instrukcje dla jezuickich nauczycieli. Są to dwa podstawowe dzieła, które umożliwiają poznanie i zrozumienie pedagogiki jezuickiej. Stanowią także przykład zdecydowanego wpływu humanizmu na szkoły europejskie w ciągu kilku stuleci. Obydwa teksty zawierają głębokie i czasem ostre uwagi na temat intelektualnej i moralnej formacji chrześcijanina. Mowa tutaj o dwóch ważnych dziełach, wieńczących życie i działalność pedagogiczną Franciszka Sacchiniego: Paraenesis ad magistros scholarum inferiorum Societatis lesu (1625) i Protrepticon ad magistros scholarum inferiorum Societatis lesu (1625) ${ }^{5}$. Poradnik (paraenesis) i napomnienia (protrepticon) adresowane były do profesorów klas niższych. Dzieła Sacchiniego stanowią swego rodzaju dyptyk, dwie części, w których głosił pochwałę nauczyciela oraz jego wielką godność. Wychowawca w jego ujęciu odgrywa rolę raczej filozofa i teologa niż gramatyka. Kariera nauczyciela jest chwalebna, godna szacunku tym bardziej, że realizowana nieodpłatnie. Wszystko, co darmowe, jest szlachetne. Poświęcenie się edukacji dzieci powinno być wielką radością i dumą. Dzieło Sacchiniego ma szczególną wartość nie tylko z racji autorytetu osobistego autora jako człowieka i doskonałego pisarza, ale także dlatego, że jego tekst był powtarzany prawie dosłownie przez autorów wywodzących się ze wszystkich pokoleń jezuitów. Zasięg jego oddziaływania był zatem ogromny. Józef de Jouvancy, którego sława sięgała o wiele dalej, zapożyczył od niego idee i wyrażenia, którymi pod koniec XVII wieku wzbogacił swoją Ratio discendi et docendi.

Pierwsza część dzieła Sacchiniego Paraenesis ad magistros scholarum inferiorum Societatis lesu (1625) podkreśla godność i znaczenie misji nauczycielskiej. Druga część wskazuje natomiast na skuteczność i użyteczność urzędu nauczycielskiego. Użyteczność to słowo klucz (De utilitate puerilis institutionis). W 21 rozdziałach Sacchini dowartościowuje siłę wychowania, które „jest źródłem prawie wszystkich dóbr ludzkich” (Charmot, 1951, s. 49). Opisuje uroki i nieszczęścia dzieciństwa, skarby, jakie ma ono w sobie, oraz zagrażające mu ze względu na jego słabość niebezpieczeństwa i jednocześnie go broni. Protrepticon ad magistros scholarum inferiorum Societatis lesu ma wymiar bardziej dydaktyczny i definiuje powinności nauczyciela niższych szkół Towarzystwa, traktuje o misji nauczyciela, o narzędziach, dzięki którym będzie mógł wypełniać on swoje obowiązki, o szacunku dla klasy, sposobach zainteresowania dzieci nauką, metodach promowania postępów w uczeniu się, ćwiczeniu pamięci, zachęcaniu do uczenia się greki, nagrodach, karach, naganach, o prowadzeniu chrześcijańskiej katechezy, kulturze bycia, przyczynianiu się do wzrostu pobożności uczniów przez własną modlitwę, pomocy uczniom przez

${ }^{5}$ Oba teksty wydane w oficynie Giacoma Mascardiego (Romae 1625). Pierwsze ich tłumaczenie opublikowano w języku niemieckim pod koniec XIX wieku. W 2017 roku ukazało się drugie tłumaczenie, w języku hiszpańskim (Sacchini, 2017). Jest to wydanie dwujęzyczne. 


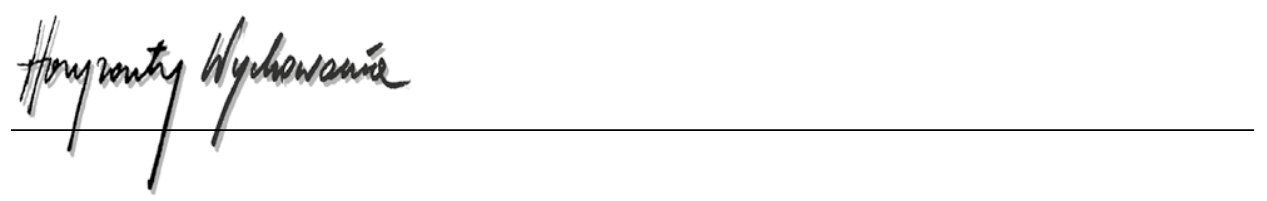

przykład, wspieraniu aktywności własnej uczniów, stosunku do kolegów nauczycieli, wreszcie o postępowaniu wobec eksternów (uczniów spoza zakonu).

Podobnie jak Sacchini, także Józef de Jouvancy doceniał misję nauczycielską i przekonywał nauczycieli, że ich praca przynosi więcej korzyści im samym niż ich uczniom. Ta korzyść polega na tym, że wymaga od nauczyciela praktykowania w życiu codziennym miłości i pokory - dwóch największych cnót ${ }^{6}$. Liczne źródła wskazują, że zasadniczą racją, dla której tak wielu jezuitów oddawało się dziełu edukacji, były właśnie pokora i miłość (Konstytucje, 2001, s. 170). Te dwie cnoty mogły się spotkać w sposób najpełniejszy w kolegiach, w klasach, w nauczaniu i wychowaniu tych najmniejszych z dzieci Chrystusa (Charmot, 1951, s. 71). Co zaś dotyczy pokory, ćwiczono się w niej w procesie wychowania nieustannie, ponieważ nauczyciel, wychowawca musiał się dostosowywać do poziomu ucznia ${ }^{7}$. Francuski jezuita Józef de Jouvancy napisał rodzaj instrukcji metodycznej pt. De ratione discendi et docendi (1692), której celem było wzmocnienie rangi studiów klasycznych w szkołach jezuickich. W przedmowie do francuskiego tłumaczenia dzieła wydawca pisze, że w odniesieniu do nauczycieli łaciński traktat de Jouvancy’ego jest

(...) koniecznym uzupełnieniem słynnej Ratio atque institutio studiorum Societatis Jesu. Zaleca profesorom kształcącym nauczycieli: przygotowujcie nauczycieli wykształconych i przestrzegających dobrych obyczajów, wprowadzajcie ich, tak jak proponuje Jouvancy, do najlepszych metod uczenia się i nauczania, a przygotujecie dobrych uczniów. Traktat $D e$ ratione discendi et docendi zawiera dobre i rozsądne spostrzeżenia dotyczące nauczycieli i uczniów, tego, kim oni są (Jouvancy, 1892).

Jouvancy pisał w nim m.in.:

Niech nauczyciel będzie przekonany, że każdy uczeń, którego ma pod opieką w klasie, jest z pewnością dzieckiem, jeśli chodzi o wiek, ale w gruncie rzeczy posiada królewską godność. W tych małych ciałach kryje się dusza, która nosi cechy swojego boskiego pochodzenia, ślady niebieskiego pokrewieństwa, a w jego żyłach płynie krew Chrystusa (...). [Nauczyciel p]owinien zatem wykonywać swoją wychowawczą misję nie tylko z radością, ale ze świętą ambicją (za: Charmot, 1951, s. 68).

W XVII wieku szkolnictwo jezuickie w Polsce zaczęło doświadczać kryzysu, którego źródłem był w dużym stopniu upadek nauczycielstwa ${ }^{8}$. Na początku XVIII wieku,

\footnotetext{
${ }^{6}$ "Quia versatur eius labor in quotidiana maximarum exercitatione virtutum, humilitatis et caritatis" (J. de Jouvancy, 1692, cz. 2, rozdz. 3, art. 3).

${ }^{7}$ Kategoria „dostosowania” jest jedną z idei przewodnich wszystkich ważniejszych jezuickich dokumentów pedagogicznych na czele z Ratio studiorum, przypominaną przez wielkich pedagogów Towarzystwa Jezusowego. Ma ono swoje źródło w Ćwiczeniach duchowych św. Ignacego, w których należy szukać genezy pedagogicznej działalności zakonu. Szczególnie w Adnotacjach nr 4, 17, 18-20 do Ćwiczeń duchowych jest mowa o dostosowaniu i jego uzasadnieniu (Królikowski, 2018, s. 107, $178 \mathrm{nn}, 250 \mathrm{nn}$.).

${ }^{8} \mathrm{~W}$ okresie upadku szkół jezuickich zawodem nauczycielskim w klasach niższych zaczęto pogardzać, traktując go jako nieprzyjemną próbę. Skutkowało to nierzetelnym wypełnianiem
} 
w okresie stopniowego odradzania się szkół jezuickich, polski jezuita Stefan Sczaniecki opublikował podręcznik pedagogiki: Professio circa puerorum in virtute sapientia et politie institutionem seu ars docendi religiose, utiliter, honeste, professoribus Societatis Jesu provinciae Polonae a P. Stephano Szczaniecki S.J. proposita (Calissii 1715) ${ }^{9}$. Stefan Sczaniecki już na wstępie swojego podręcznika pedagogiki podkreślał godność zawodu nauczyciela:

Zaiste (...) jest to rzecz najważniejsza w swym rodzaju - być profesorem i nauczycielem w szkole; nie z przypadku lub dla zapłaty, ale za darmo, z czystego zamiłowania i na mocy ślubowanej profesji zakonnej (Kochanowicz, 2001, s. 31).

W pierwszym rozdziale Sczaniecki pisze o formacji duchowej kandydatów na nauczycieli, rozdział drugi poświęcony jest formacji naukowej, intelektualnej, natomiast w trzecim rozdziale mowa jest o sposobie zachowania się, postępowania dobrego nauczyciela. W takim podejściu ujawnia się wiedza pedagogiczna Sczanieckiego. Dobry nauczyciel szkoły jezuickiej powinien być dojrzały duchowo, intelektualnie, metodycznie i dydaktycznie. Nauczyciel powinien być wzorem osobowym. Tylko wówczas będzie możliwe jego oddziaływanie na ucznia. Nauczyciel powinien być również ekspertem w zakresie nauczanego przedmiotu, aby był w stanie pokierować uczniem w jego osobistej drodze rozwoju, wreszcie powinien opanować metody pracy z uczniem, nabyć sprawności metodycznych, dzięki którym pomoże uczniom w efektywnym uczeniu się.

Bardziej niż tysiąckroć bylibyśmy biednymi nauczycielami, pożałowania godnymi i najnieszczęśliwszymi wśród najgorszych zarządców szkół, gdybyśmy więcej lub tyle samo wysiłku poświęcali na zdobycie wiedzy dla siebie samych i dla naszych uczniów, ile na pracę nad własnym sumieniem i nad sumieniem uczniów. Gdybyśmy tyle samo sił wkładali w postęp w nauce, ile w życiu wewnętrznym, tyle na język łaciński, ile (a nie tysiąckroć więcej!) na pobożność (Kochanowicz, 2001, s. 43).

Najważniejsze w edukowaniu nauczycieli było zatem kształtowanie ich w cnocie, w dobrych obyczajach. Dzięki takiemu podejściu mogli oni budować swój autorytet osobowy, a tym samym oddziaływać na wychowanków nie tylko słowem, ale przede wszystkim przykładem. To oddziaływanie powinno uwzględniać wyjątkowość, indywidualność każdego ucznia. Jest bardzo niebezpieczne, zdaniem Ignacego, prowadzić wszystkich do doskonałości i wiedzy tą samą drogą (Selectae S.P. Ignatii Sententiae, 1948, nr 8). Nauczyciel ma świadomość, że winien przekazać wszystkim uczniom tę samą wiedzę. Jest to warunek realizowania edukacji w grupie. Jednocześnie wie również, że jego uczniowie w różny sposób przyswajają tę wiedzę, dlatego musi kierować pracą każdego z podopiecznych w taki sposób, jakby pracował tylko z jednym uczniem. Te zasady

obowiązków, a w konsekwencji prowadziło do ugruntowania się metody pamięciowej. Takie postawy były surowo potępiane i karcone przez przełożonych (por. Bednarski, 1933, s. 181-182).

${ }^{9}$ Jego edycję w tłumaczeniu polskim przygotował Jerzy Kochanowicz (2001). 


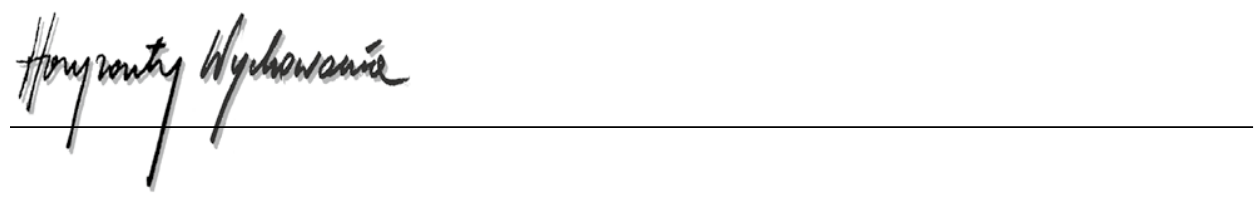

indywidualizacji kształcenia i adaptacji do możliwości ucznia zostały zawarte w Ratio studiorum i pozostają w zgodzie ze sztuką dawania ćwiczeń duchowych. Dziesięć pierwszych rozdziałów Dyrektoriów do Ćwiczeń duchowych ${ }^{10}$ jest świadectwem takiego właśnie podejścia. Zastosowane do edukacji, uwypuklają zasadę pedagogiczną, że najważniejszą rolą nauczyciela nie jest nauczanie, lecz spowodowanie, aby uczeń zrobił postęp w odkrywaniu prawdy. Wysiłek nauczyciela powinien skupić się najpierw na nim samym, aby nabrał osobistego doświadczenia pracy (Dyrektorium, rozdz. V), następnie na psychologii ucznia, aby mógł dostosować metody do indywidualnych temperamentów i do wszystkich uwarunkowań indywidualnych rozwoju (Dyrektorium, rozdz. I-X, a zwłaszcza IX), wreszcie na aktywności własnej uczniów tak, aby każdy osobiście odkrywał prawdę z odwagą i mądrością (Dyrektorium, rozdz. I-X, a zwłaszcza II i III) (Charmot, 1951, s. 146-151).

W jednym z podręczników metodycznych dla nauczyciela, wykorzystywanych we wszystkich prowincjach zakonu, zawarte są wskazania dla nauczyciela, jak zyskać szacunek i autorytet u uczniów. Nauczyciel będzie lubiany i szanowany, jeśli uczniowie

(...) będą widzieć, że pragnie ich postępu, że jest umiarkowany i panuje nad gniewem, że nie jest podejrzliwy i łatwowierny, [że jest] łagodny i ludzki prywatnie, a na serio postępujący i poważny publicznie, [że] będzie pokazywał równe usposobienie i konsekwencję w postępowaniu, jednakową dla wszystkich sprawiedliwość, [że] dla żadnego nie będzie bardziej życzliwy i z nikim nad miarę poufały. Winien być powściągliwy w karaniu, powodując się w nim nie nienawiścią, ale jedynie miłością i wtedy, gdy jest to absolutnie konieczne; dlatego należy chętnie korzystać z okazji do podarowania lub zmniejszenia kary. (...) Miłość uczniów zdobędzie sobie również nauczyciel przez troskę o wszystko, co ich dotyczy, o ich zdrowie, sławę, wykształcenie, pobożność, a nawet różne wygody. Niech pomaga słabym, odwiedza chorych, broni opuszczonych, niech dla wszystkich, a zwłaszcza dla nowo przybyłych i ubogich będzie troskliwym ojcem i kochającą matką. (...) Niech będzie sumienny w wymaganiach stawianych uczniom, ale bez męczącej surowości. Niech nie wymaga wszystkiego od wszystkich; należy pochwalić wysiłki, gdy nie można pochwalić wyników (Jouvancy, 1703, s. 126-124).

Niezbędnym elementem budowania autorytetu nauczycielskiego, a zarazem przejawem szacunku dla dziecka, jest punktualność (ut punctualitatem scrupulosissime observet). Stefan Sczaniecki w swoim podręczniku pedagogicznym przypomina nauczycielom, że lekcje powinny być prowadzone do końca, nie tracąc nawet ostatniego kwadransa na czczą gadaninę (Kochanowicz, 2001, s. 99).

Szkoły jezuickie kształciły uczniów reprezentujących różne stany. Ratio studiorum mocno akcentowało obowiązek traktowania wszystkich uczniów z należytym szacunkiem. Troskę o praktyczną realizację tego wymagania widać w specjalnej regule prefekta

${ }^{10}$ Directorium in exercitia spiritualia B.P.N. Ignatii, in Collegio Romano eiusdem Societatis, Romae 1615. Jest to dokument dotyczący sposobu udzielania ćwiczeń duchowych. Wskazano w nim, w jaki sposób należy interpretować Ćwiczenia i jak mają być one praktykowane (por. Królikowski, 2015a). 
klas niższych, która zakazywała nauczycielowi wysługiwania się uczniami (nawet tymi wywodzącymi się ze stanu plebejskiego) w załatwianiu swoich prywatnych spraw ${ }^{11}$.

Myśl pedeutologiczna zrekonstruowana na podstawie lektury najważniejszych dzieł staropolskich jezuickich pedagogów kształcących nauczycieli dla szkół jezuickich odzwierciedla ówczesne myślenie o głównych aktorach procesu edukacyjnego: uczniach i nauczycielach. Pozwala na odczytanie roli każdego z nich, a także ich wzajemnej relacji w procesie kształcenia i wychowania. Centralną pozycję zajmuje w nim uczeń, posiada on „królewską godność”, nauczyciel zaś pełni rolę służebną, wymagającą z jednej strony pokory (zasada dostosowania, indywidualizacji), a z drugiej - wszechstronnego i gruntownego przygotowania zawodowego, które zakłada posiadanie kompetencji merytorycznych, dydaktycznych, metodologicznych i osobowościowych.

\section{BIBLIOGRAFIA}

Źródła

Directorium in exercitia spiritualia B.P.N. Ignatii, in Collegio Romano eiusdem Societatis, Romae 1615.

Bonifacio, J. (1575). Christiani pueri institutio, adolescentiae que perfugium: ad gymnasia eiusdem Societatis. Matias Gast (Salamanca).

Jouvancy, J. de. (1692). Christianis litterarum magistris De ratione discendi et docendi. B.w. (Parisiis). Jouvancy, J. de. (1703). Magistris scholarum inferiorum Societatis lesu De ratione discendi et docendi. Michele Nestenius (Florentiae).

Kochanowicz, J. (red.). (2001). Podręcznik pedagogiki Stefana Sczanieckiego SJ z 1715 roku. Professio circa puerorum in virtute, sapientia et politie institutionem (J. Ożóg, tłum.). Wyższa Szkoła Filozoficzno-Pedagogiczna Ignatianum, Wydawnictwo WAM.

Ratio studiorum (2000). Ratio atque institutio studiorum SJ, czyli Ustawa szkolna Towarzystwa Jezusowego (1599) (K. Bartnicka i T. Bieńkowski, wstęp i oprac.). Wydawnictwo Naukowe Ateneum.

Sacchini, F. (1625). Paraenesis ad magistros scholarum inferiorum Societatis lesu. Typis lacobi Mascardi (Romae).

Sacchini, F. (1626). Protrepticon ad magistros scholarum inferiorum Societatis lesu. Formis Academicis. Apud lacobum Sermodi (Diling).

Selectae S.P. Ignatii Sententiae, (1948). W: Thesaurus Spiritualis Societatis lesu. Typis Polyglottis Vaticanis (Romae).

\section{Opracowania}

Alves Dias, J.J. (2014). Os primeiros caracteres europeus impressos na China, 1588. PortugalChina: 500 anos (M. Castelo-Branco i P.S.J. Barata, red.), Biblioteca Nacional de Portugal. Anzenbacher, A. (2006). Co oznacza "godność człowieka”? Horyzonty Wychowania, 5(9), 53-71. Bednarski, S. (1933). Upadek i odrodzenie szkół jezuickich w Polsce. Studjum z dziejów szkolnictwa polskiego. Wydawnictwo Księży Jezuitów.

11 „Prefekt w żadnym czasie nie może sam i ma nie pozwolić innym korzystać z pracy uczniów do pisania czy do innej rzeczy”. Reguły prefekta klas niższych, nr 48 (Ratio studiorum, 2000, s. 78). 


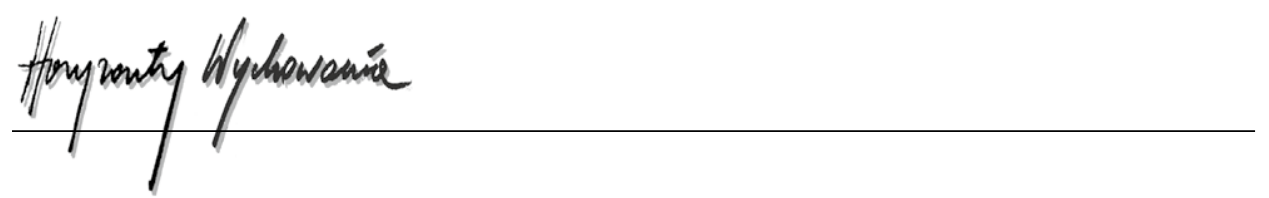

Bronk, A. (2010). Kategoria godności człowieka. Annales Universitatis Mariae Curie-Skłodowska, 35(1), 77-96.

Chałas, K. (2021). Godność człowieka źródłem celów wychowania i zadań szkoły. Roczniki Pedagogiczne, 13(49), 2, 33-48. https://doi.org/10.18290/rped21132.3

Charmot F. (1951). La pédagogie des jésuites. Ses principes, son actualité. Éditions Spes.

Chlewiński, Z. i Zaleski, Z. (1989). Godność. W: L. Bieńkowski i in. (red.), Encyklopedia katolicka (t. 5, kol. 1231-1232). Towarzystwo Naukowe KUL.

Delgado B. (2002). La educación en la reforma y la contrarreforma. Síntesis Educación.

Konstytucje Towarzystwa Jezusowego wraz z przypisami Kongregacji Generalnej XXXIV oraz Normy uzupełniające zatwierdzone przez tę samą Kongregacją. (2001). Wydawnictwo WAM, Polskie Prowincje Towarzystwa Jezusowego.

Królikowska, A. (2019). Kształcenie nauczycieli dla jezuickich szkół średnich w Polsce od XVI do XVIII wieku. Wydawnictwo Naukowe Akademii Ignatianum w Krakowie.

Królikowski, W. (2015a, 25 kwietnia). Dyrektoria do Ćwiczeń duchowych św. Ignacego Loyoli i ich powstanie. Centrum Duchowości. https://czestochowa-jezuici.pl/2015/04/25/dyrektoria-do-cwiczen/

Królikowski, W. (2015b, 25 kwietnia). Kierownictwo duchowe w Ćwiczeniach duchowych św. Ignacego Loyoli jako ważny element pedagogii ignacjańskiej. Centrum Duchowości. https:// czestochowa-jezuici.pl/2015/04/25/kierownictwo-duchowe/

Królikowski, W. (2018). Adnotacje do Ćwiczeń duchowych św. Ignacego Loyoli. Studium teologiczno-pastoralne. Wydawnictwo Naukowe Akademii Ignatianum w Krakowie.

Mariański, J. (2019). Godność ludzka jako wartość i sposoby jej uzasadniania w opinii młodzieży. Zeszyty Naukowe KUL, 62(4), 5-29.

Mariański, J. (2020). Godność osobista w ocenie młodzieży - analiza teoretyczno-empiryczna. Horyzonty Wychowania, 19(50), 27-44.

Sacchini, F. (2017). Exhortación y Preceptiva para los maestros de escuelas inferiores de la Compañía de Jesús (A. Martínez Sobrino i J. Laspalas Pérez, tłum., wstęp i red.). Editorial UNED.

Stępień, K. (2016). Godność osobowa. W: K. Chałas i A. Maj (red.), Encyklopedia aksjologii pedagogicznej (s. 377-378). Polskie Wydawnictwo Encyklopedyczne Polwen.

de Tchorzewski, A.M. de. (2020). Rzecz o godności, autorytecie i odpowiedzialności nauczyciela w czasach chaosu aksjonormatywnego. Horyzonty Wychowania, 19(50), 161-176.

Vergara Ciordia, J. (2012). La edición de Burgos de 1588 del "Christiani pueri institutio adolescentiaeque perfugium", obra clave del humanismo jesuítico hispano. Historia de la Educación: Revista interuniversitaria, 31, 81-103.

Żołądź-Strzelczyk, D. (2002). Wychowanie dziecka w świetle staropolskiej teorii pedagogicznej. W: M. Dąbrowska i A. Klondera (red.), Od narodzin do wieku dojrzałego. Dzieci i młodzież w Polsce. Cz. 1: Od średniowiecza do wieku XVIII (s. 96-108). Warszawa: Instytut Archeologii i Etnologii PAN.

\section{Copyright and License}

This article is published under the terms of the Creative Commons Attribution - NoDerivs (CC BY- ND 4.0) License http://creativecommons.org/licenses/by-nd/4.0/ 